\title{
PERSEPSI PENGARANG ATAS DUNIA SOSIAL BALI
}

\author{
I. B. Putera Manuaba \\ Jurusan Sastra Indonesia \\ Fakultas Ilmu Budaya, Universitas Airlangga Surabaya
}

\begin{abstract}
This study analyzes authors' perception of the Balinese social world, focusing on social changes as effects of tourism and modernization. The study employed the qualitative approach involving the sociology of literature, especially the sosiology of authors. Berger's social contruction theory was used as a triangulation technique. The study shows the following findings. First, the Balinese authors subjectively propose a reconstruction of the modern Balinese people's way of thinking to face modernization or changing conditions. Second, the Balinese authors are ambiguous people, in the sense that on the one hand they criticize Bali, and on the other hand they love Bali. Third, the Balinese authors offer truths that are not dogmatic in nature but derived from daily experiences.
\end{abstract}

Keywords: author plurality, social world, plurality

\section{A. PENDAHULUAN}

Dunia sosial Bali kini merupakan dunia yang kompleks, sebagai akibat dari pesatnya dunia pariwisata dan modernisasi di Bali. Kekompleksannya ini berimplikasi pada terjadinya berbagai perubahan dalam sistem sosial dan tatanilai yang ada. Juga berakibat terjadinya konflik sosial dan kultural. Bahkan sampai tahun 2007 konflik sosial terus terjadi, seperti terjadinya kerusuhan antarwarga di Desa Tusan, Klungkung, Bali (Kompas, April 2007). Kejadian itu hanya sebagian kecil yang mencuat ke permukaan, sebagai cerminan Bali menghadapi banyak masalah yang belum terpecahkan.

Orang Bali menempatkan modernitas sebagai yang penting sedangkan tradisi kurang penting. Ada juga orang Bali yang menganggap tradisi sebagai tujuan, sedangkan modernitas sebagai alat. Ketika modernitas diunggulkan, tradisi diabaikan. Namun, ketika orang Bali menjalani modernitas - tanpa tersadariacapkali kembali kepada tradisi. Ia ingin menjadi orang modern, padahal kesadaran tradisinya lebih kuat.

Pengarang Bali yang hidup dan mengalami dunia sosial itu, mencoba menata dan mencari hubungan antara keduanya.
Brahmana misalnya, bukannya harus saling berkontradiksi dengan golongan yang lain, tetapi seharusnya ada bersama-sama ksatria, wesia, dan sudra. Ketegangan yang terjadi, sebagai akibat perubahan sosial dan kultural, memang masih belum memiliki penyelesaian dan bahkan terus terjadi dan bertambah (Putra, Kompas, Desember 2003). Dunia sosial Bali yang tengah berubah, yang berada dalam kultur modernitas, tidak hanya menjadi perhatian intelektual Bali, tetapi juga pengarang Bali. Atas kondisi dunia sosial Bali itu, pengarang selaku anggota masyarakat Bali mencurahkan kediriannya, mencoba merespons dengan mengekspresikannya ke dalam sastra. Berdasarkan latar belakang masalah tersebut, tujuan penelitian ini mengungkapkan pluralitas dan persepsi pengarang Bali atas dunia sosialnya dimana mereka mencoba memahami dan melakukan penataan-ulang secara subjektif.

Wellek dan Warren (1989:112) menyatakan bahwa setiap pengarang adalah warga masyarakat, ia dapat dipelajari sebagai makhluk sosial (homo social). Karena itu, biografi pengarang adalah sebagai sumber utama, dan juga dapat meluas ke lingkungan sosial pengarang dimana ia berasal dan hidup. 
Untuk mempelajari pengarang, semua informasi dapat dikumpulkan menyangkut latar belakang sosial, latar belakang keluarga, dan posisi ekonomi pengarang. Selebihnya dapat juga dilihat peran sosialnya dalam masyarakat.

Teori tersebut dipertajam dengan teori konstruksi sosial (social construction) Berger yang berpijak pada sosiologi pengetahuan, yang mendasarkan pengetahuannya dalam dunia kehidupan sehari-hari sebagai kenyataan. Bagi Berger (1990:31-32), kenyataan kehidupan sehari-hari dianggap menampilkan diri sebagai kenyataan par excellence sehingga disebutnya sebagai kenyataan utama (paramount). Berger (1990:28) menyatakan dunia kehidupan sehari-hari menampilkan diri sebagai kenyataan yang ditafsirkan manusia, yang dipersepsi pengarang. Dunia kehidupan sehari-hari yang dialami pengarang tidak hanya nyata tetapi juga bermakna. Kebermaknaannya subjektif, dianggap benar seperti yang dipersepsi pengarang.

Pengarang adalah anggota masyarakat, yang memiliki hubungan erat dengan masyarakat dimana ia hidup dan menciptakan karyanya. Sebagai anggota masyarakat, pengarang terikat oleh status sosial tertentu (Damono, 1994:1). Karena keterikatannya, dalam proses penciptaan sastra, mau tidak mau, ia memahami totalitas kehidupan sosial masyarakat yang melingkunginya. Aristotetes menyatakan pengarang tidak meniru kenyataan sebagaimana adanya tetapi menciptakan dunianya sendiri sebagai sarana pengetahuan yang khas (Teeuw, 1984:222).

Pengarang melakukan internalisasi atas dunia sosialnya tempat ia hidup dan mengembangkan dirinya; sama halnya seperti yang dilakukan anggota masyarakat lainnya. Ia menginternalisasi lembaga-lembaga dan organisasi-organisasi sosial yang ada di dalam masyarakatnya, dan ia juga memainkan peranan-peranan tertentu dalam kehidupan sosialnya. Internalisasi atas dunia sosial atau masyarakatnya dilakukan melalui sosialisasi, yakni sosialisasi primer dan sekunder.

Dalam waktu yang bersamaan, pengarang mencurahkan kediriannya terus- menerus ke dalam dunia sosialnya. Hasil pencurahan kediriannya secara intens dan terus-menerus ke dalam dunia sosialnya, diekspresikan ke dalam karya sastra. Bagi Berger (1990:32), kenyataan hidup sehari-hari sebagai kenyataan yang tertib dan tertata. Fenomen-fenomennya seperti sudah tersusun sejak semula dalam bentuk pola-pola, yang tidak tergantung kepada pemahaman seseorang.

Kenyataan hidup sehari-hari dialami bersama oleh orang-orang, termasuk pengarang di dalamnya. Pengalaman terpenting orangorang berlangsung dalam situasi tatap-muka, sebagai proses interaksi sosial (Berger, 1990:41). Dalam situasi tatap-muka ini, orangorang terus-menerus saling bersentuhan, berinteraksi, dan berekspresi.

Dalam konteks itu, pandangan Berger (1990:47) dapat dimengerti bahwa kenyataan sosial kehidupan sehari-hari dipahami dalam suatu rangkaian (continuum) berbagai tipifikasi, yang menjadi semakin anonim dengan semakin jauhnya tipifikasi itu dari $d i$ sini dan sekarang dalam situasi tatap-muka. Pada satu sisi, di dalam rangkaian itu terdapat orang-orang yang saling berinteraksi secara intensif dalam situasi tatap-muka; dan di sisi lain, terdapat abstraksi-abstraksi yang sangat anonim karena sifatnya yang tidak terlibat dalam tatap-muka.

Produk aktivitas manusia-yang berupa produk-produk sosial-terlahir dari eksternalisasi manusia. Eksternalisasi adalah suatu pencurahan kedirian manusia secara terus-menerus ke dalam dunia, baik dalam aktivitas fisis maupun mentalnya. Ia merupakan keharusan antropologis, yang tidak mungkin berlangsung dalam suatu lingkungan interioritas yang tertutup. Keberadaan manusia harus terus-menerus mencurahkan kediriannya dalam aktivitas (Berger, 1990:75).

\section{B. METODE PENELITIAN}

Dalam penelitian ini dimanfaatkan pendekatan kualitatif-observatif, dengan studi kasus internal yang berupa persepsi tentang masyarakat, khususnya persepsi pengarang 
Bali tentang masyarakat Bali. Persepsi pengarang dikaji berdasarkan hasil wawancara dengan empat pengarang Bali (Oka Rusmini, Putu Fajar Arcana, Putu Wijaya, dan Wayan Sunarta).

Objek penelitian ini adalah dunia sosial Bali, yang tengah mengalami krisis - dari masyarakat Bali tradisional ke modern, yang dipersepsi pengarang Bali. Karena itu, pemahaman dilakukan melalui hasil wawancara terhadap empat pengarang Bali (Oka Rusmini, Putu Fajar Arcana, Putu Wijaya, dan Wayan Sunarta) yang menyangkut persepsi atas dunia sosial Bali beserta pengalaman hidupnya dalam masyarakat Bali yang telah mengalami modernisasi.

Data yang berupa persepsi pengarang Bali atas masyarakat Bali dan pengalaman hidupnya dalam dunia sosial masyarakat Bali; dikumpulkan melalui strategi in-depth interview (wawancara mendalam); serta melengkapinya dengan dokumen dan ingatan empiris peneliti.

Data dan informasi yang telah dikumpulkan melalui metode dokumen dan wawancara mendalam (in-depth interview), diteruskan ke tingkat analisis. Teknik analisis yang digunakan adalah: teknik catat dan interpretasi. Teknik catat, digunakan untuk mencatat pengalaman hidup pengarang dalam kehidupan dunia sosial Bali, guna mengungkap dunia sosial Bali; teknik interpretasi, digunakan untuk menginterpretasi maknanya secara sosiologis.

\section{HA S IL PENELITIAN DAN PEMBAHASAN}

Dunia sosial pengarang adalah dunia eksternal karya yang memiliki keterkaitan erat dengan karya. Dunia ini mengungkapkan bahwa dalam dunia sosial yang bagaimana pengarang Bali hidup, mengembangkan diri, dan menciptakan karya-karya cerpennya. Semua itu dipakai menjelaskan sejauh mana dunia sosial pengarang berkaitan dengan dunia sosial karya yang dilukiskan pengarang dalam cerpennya.
1. Pengarang dalam Sistem Sosialnya

Pengarang Bali adalah anggota masyarakat Bali. Mereka terikat dengan sistem sosial masyarakat yang melingkunginya. Pengarang menciptakan cerpen yang melukiskan dunia sosial dengan berbagai persoalannya, sangat ditentukan juga oleh sistem sosial yang yang melingkunginya.

\subsection{Pengarang dalam Sistem Pengelompokan Sosialnya \\ Pengarang Bali yang hidup dalam} masyarakat Bali adalah anggota masyarakat yang terikat dengan kelompok sosialnya. Keempat pengarang Bali, yakni Oka Rusmini, Putu Fajar Arcana, Putu Wijaya, dan Wayan Sunarta. Pengarang Bali itu termasuk kelompok sosial griya (puri) dan jaba. Namun, kemudian mereka sekaligus juga termasuk anggota kelompok sosial lain secara tumpang-tindih.

Betapa kompleksnya kelompok sosial yang melingkungi pengarang Bali. Mereka tidak saja menjadi anggota kelompok griya atau jaba, tetapi sekaligus kelompok banjar, desa, kota, pendidikan modern, dan profesional. Pola-pola yang ada secara bersama-sama mempengaruhi kediriannya. Kelompok sosial itu, dalam diri pengarang saling berkompetisi, mengungguli, dan kemudian membuatnya ada yang lebih dominan tampak dalam diri masingmasing pengarang itu.

Rusmini (Ida Ayu Oka Rusmini) yang dilahirkan di Jakarta tanggal 11 Juli 1967, melewatkan masa kanak-kanaknya dalam sosialisasi primer di Jakarta, dan mengalami sebagian sosialisasi sekunder juga di Jakarta, hanya sampai Sekolah Menengah Pertama (SMP) kelas tiga. Selanjutnya, ia pindah ke SMP Negeri I Denpasar, Bali. Setamat SMP, Rusmini melanjutkan ke SMUN II Denpasar (1984-1987); kemudian meneruskan ke Jurusan Sastra Indonesia Fakultas Sastra Universitas Udayana, Denpasar (tamat tahun 1992).

Sampai SMP kelas tiga, Rusmini belum mengalami hidup dalam suasana keluarga griya, tetapi mengalami hidup dalam rumah biasa di Jakarta. Ketika itu, Rusmini hidup 
dalam rumah keluarga biasa yang ayahnya adalah seorang Kopasus. Jadi, dari pengakuan Rusmini, ayahnya tidak pernah mengajarkan bagaimana eksistensi dirinya sebagai seorang brahmana (wawancara, 10 Januari 2007), meskipun ia dilahirkan dalam keluarga brahmana. Ketika Rusmini hidup di Jakarta, ia memang sudah sadar dirinya adalah orang Bali, dan dapat membayangkan kehidupan dunia Bali yang eksotis dan indah (wawancara, 10 Januari 2007).

Sosialisasi sekunder Rusmini kemudian dilanjutkan dalam keluarga griya di Bali sejak tahun 1981 hingga dewasanya. Namun, dari pengakuan Rusmini (wawancara, 10 Januari 2007), ia tidak tinggal di dalam keluarga besar griya tetapi di luar lingkungan keluarga griya, yang masih dekat berhadaphadapan dengan griya.

Dilihat dari nama depannya yakni ida $a y u$, Rusmini memiliki gen-ekologis kasta brahmana. Namun, masalahnya, ia tidak terlalu peduli dengan kasta; ia tidak mempersoalkan apakah dirinya brahmana atau tidak brahmana. Sikap Rusmini ini tampak diekspresikan dalam beberapa tokoh di dalam cerpen-cerpennya, di antaranya pada tokoh "Sagra" yang tidak terlalu mempedulikan apakah dirinya berasal dari keluarga brahmana atau sudra (wawancara, 10 Januari 2007).

Bagi Rusmini, sikapnya ini dipengaruhi oleh keberadaan dirinya yang tidak lahir dan dibesarkan dalam keluarga griya, tetapi dalam keluarga biasa di Jakarta. Dari pengakuan Rusmini (wawancara, 10 Januari 2007), gugatan-gugatan yang dilontarkannya dan proses kreatif menulisnya ternyata sangat dipengaruhi juga oleh pendidikan Khatolik yang pernah dialaminya (wawancara, 10 Januari 2007). Ketika harus ke Bali dan tinggal di Bali, awalnya Rusmini mengalami shock culture (keterkejutan budaya) (wawancara, 10 Januari 2007). Shock culture yang dialami Rusmini ini erat kaitannya dengan tidak adanya kesamaan antara apa yang dibayangkan Rusmini tentang Bali ketika ia ada di Jakarta (luar Bali) dan apa yang ia alami ketika pertama kali tinggal di Bali.
Dalam lanjutan sosialisasi sekunder, Rusmini mengalami sosialisasi relatif banyak dengan keluarga griya, sebagai tempat dan dunia sosialnya yang baru. Dalam keluarga griya, ia terlibat dalam segala aktivitas sosial di griya, dan ia menjadi pengempon (wawancara, 10 Januari 2007). Setelah melewati masa kecilnya di Jakarta, kini ia mengalami hidup dalam keluarga griya.

Dalam kelompok griya yang demikian, Rusmini dikenalkan dengan norma-norma yang berlaku dalam kelompok itu yang menyangkut adat dan tatakrama. Aturan-aturan dan normanorma kelompok itulah yang diinternalisasi oleh Rusmini dalam kelompok griya, yang melalui proses sosialisasi terjadi secara asimetris.

Orang-orang yang ada dalam kelompok griya menanamkan misalnya cara berpakaian bersih dan suci dan selalu berkata dengan bahasa yang santun. Sosialisasi dari orang-orang yang dari kelompok griya itu memaksa Rusmini mengidentifikasikan dirinya dengan orang-orang itu, kendatipun yang kemudian terjadi adalah asimetri.

Rusmini juga sekaligus menjadi anggota kelompok banjar dan anggota kelompok desa, kota, kelompok pendidikan modern, dan juga kelompok profesional. Ia terlibat dalam kegiatan kelompok banjar dan desa karena tinggal di banjar dan desa. Polapola banjar dan desa juga mempengaruhinya. Ia sekaligus juga menyerap pola-pola yang dimiliki kelompok kota. Sejak di Jakarta hingga Denpasar, Rusmini juga menjadi kelompok terdidik modern. Ia menempuh pendidikan dari tingkat sekolah dasar hingga perguruan tinggi. Pendidikan yang diterimanya adalah pendidikan modern. Ketika di kota Denpasar, tahun 1992, ia sekaligus menekuni profesi sebagai Redaktur Tamu Mingguan Prima PT Bali Post; bekerja sebagai redaktur Bali Post Minggu (Rubrik Mode, Kesehatan, dan Keluarga); serta tahun 1998-2000 sebagai penanggung jawab tabloid remaja Bali "Wiyata Mandala" Bali Post (wawancara, 7 April 2007).

Putu Fajar Arcana, dilahirkan pada sebuah kota paling Barat Pulau Bali, bernama 
Desa Loloan, Kabupaten Jembrana yang ibukotanya adalah Negara. Kabupaten ini, karena dekat dengan Jawa maka relatif lebih dahulu mengalami pembauran dengan orangorang Jawa atau luar Bali. Kondisi kota Jembrana itu sangat heterogen dan berpengaruh kepada kehidupan Arcana. Ini menjadi catatan penting dalam pengalaman kehidupan Arcana, yang mempengaruhi pola pikirnya (wawancara, 13 Januari 2007).

Arcana lahir tahun 1965, di dalam lingkungan keluarga yang berkasta orang kebanyakan (gen-ekologis sudra). Kelompok ini merupakan kelompok informal (informal group) yang tidak terlembaga, dan ada pada kabupaten yang heterogen dan "paling tidak Bali”, yang mempengaruhi Arcana selaku pengarang, dan terekspresikan dalam cerpencerpennya.

Sebagai kelompok jaba, pada masa kanak-kanaknya ia tidak mengalami kerumitan-kerumitan adat, namun ia lebih mengalami persoalan kelompok atau komunal. Ia menginternalisasi nilai-nilai sebagaimana yang dilakukan dalam kelompoknya. Ia hidup dalam keluarga Bali yang orang tuanya kebetulan keduanya berpendidikan modern, dan telah berbahasa Indonesia (wawancara, 13 Januari 2007).

Arcana juga sekaligus adalah anggota kelompok banjar dan desa. Ia sekaligus menjadi kelompok kota, terdidik modern, dan profesional, terutama ketika berada di kota Denpasar. Pola-pola yang ada dalam kelompok banjar, desa, kota, pendidikan modern, dan profesional ini juga yang mempengaruhi Arcana, yang membuatnya mampu melukiskan kisah-kisah cerpennya yang tidak hanya mempersoalkan tentang kehidupan masyarakat banjar atau desa, tetapi juga sikap hidup kelompok orang kota dan kelompok profesional.

Ketika Arcana sekaligus ada dalam kelompok kota, kelompok terdidik modern, dan kelompok profesional, ia mampu menulis cerpen dan berani melontarkan gugatangugatannya pada adat yang pernah dipendamnya dalam waktu yang sangat lama, yakni sejak kecil, ketika masih di desanya (wawancara, 13 Januari 2007). Pengaruh kelompok-kelompok tersebut, sangat berperan dalam membangkitkan keberanian Arcana untuk melontarkan gugatannya kepada adat Bali dan orang Bali yang dinilainya harus memiliki pola pikir yang berubah.

Putu Wijaya, berasal dari kelompok sosial puri. Ia dilahirkan pada tanggal 11 April 1944 di lingkungan keluarga puri yang masih kental dengan pola-pola dalam kelompok puri, yakni sebuah kerajaan yang bernama Puri Anom di Kapubaten Tabanan, Bali; sebuah kota kabupaten kedua dari Barat. Ia bernama lengkap I Gusti Ngurah Putu Wijaya. Ia tinggal di kompleks perumahan besar, yang dihuni sekitar 200 orang, yang semua keluarganya dekat dan jauh, dan punya kebiasaan membaca.

Di puri itulah Wijaya melakukan internalisasi melalui sosialisasi primernya; dengan orang-orang berpengaruh. Ia hidup dalam belenggu adat-istiadat kerajaan dan tradisi yang sangat ketat dan fanatik. Itulah dunia sosial Wijaya di masa kanak-kanak. Ketika itu, ia sekaligus juga menjadi anggota kelompok banjar dan desa. Ia juga dipengaruhi oleh pola-pola yang ada dalam kelompok banjar dan desa.

Wijaya mengalami sosialisasi primer dan sebagian sekunder hanya sampai tingkat Sekolah Menengah Pertama (SMP); yakni ketika masa kanak-kanak dan ketika di SR Tabanan (1956), dan SMP Negeri, Tabanan (1959). Selanjutnya, Wijaya keluar dari kelompok puri karena melanjutkan sekolahnya di Sekolah Menengah Atas-A, Singaraja (1962). Ia melanjutkan studi di Fakutas Hukum (1969), ASRI dan ASDRAFI, Yogyakarta, dan studi di LPPM Jakarta (1981). Wijaya kemudian menetap di kota metropolitan Jakarta, dan pernah tinggal di Jepang (1973), serta pernah menempuh International Writing Programme, Iowa, AS (1974).

Wijaya juga adalah anggota kelompok kota sehingga banyak menyerap pola-pola kelompok kota dan kelompok terdidik modern. Terlebih lagi, Wijaya sendiri juga memiliki profesi multidimensi sebagai wartawan, 
seniman, dan budayawan. Hal ini membuat dirinya juga masuk ke dalam kelompok profesional. Wijaya memang sudah lama tidak lagi menjadi anggota kelompok banjar atau desa, karena ia tinggal dan menetap berpindahpindah.

Wijaya sadar dirinya berasal dari kelompok puri, kelompok yang berkasta tinggi ksatria, kendatipun ia tidak suka dibedakan dengan teman-teman lainnya. Ia sadar manusia tidak dapat dibedakan kualitasnya atas kasta. Karena itu, sejak kecil ia tidak hanya bergaul dengan kelompoknya sendiri tetapi juga dengan orang lain (wawancara, 31 Januari 2007).

Pengarang Bali terakhir, yang berumur paling muda adalah Wayan Sunarta. Ia lahir di Denpasar tanggal 22 Desember 1975. Ia berasal dari kelompok sosial jaba, sama seperti Arcana. Masa kanak-kanak ia lewati dalam sebuah keluarga Bali di kota Denpasar; ia sejak kecil diajari norma-norma dan sikap-sikap sebagai orang Bali oleh orang-orang yang berpengaruh pada dirinya, seperti ayah dan ibunya. Kehidupannya yang bertempat di kota, membuat keterpengaruhan kelompok kota jauh lebih besar ketimbang kelompok lainnya yang juga ia menjadi anggotanya yakni banjar dan desa. Ini diakuinya sehingga membuatnya lebih fasih berbahasa Indonesia ketimbang bahasa Bali (wawancara, 11 Januari 2007).

Kendatipun sejak kecil Sunarta hidup dalam lingkungan keluarga Bali, namun ia mengakui kurang akrab atau respek terhadap adat Bali (wawancara, 11 Januari 2007). Sejak kecil ia memang diperkenalkan dengan adat Bali, ia tentu saja juga dilatih mengerjakan pekerjaan adat, walau hanya sekedar ikutikutan dan belum banyak mengerti. Itulah awal mula ia diajari mengenal nilai-nilai tradisi. Pola-pola kelompok kota jauh lebih dominan mempengaruhi kedirian Sunarta selaku pengarang Bali. Ini terutama tampak dari lebih fasihnya Sunarta menggunakan bahasa Indonesia ketimbang bahasa Bali, termasuk dalam menuliskan cerpennya (wawancara, 11 Januari 2007).

Sunarta merasakan lingkungan masyarakat dengan berbagai kisahnya yang unik, aneh, dan beraneka-ragam, memang menjadi inspirasi untuk menciptakan cerpennya. Juga jagad pewayangan dan seni tradisi lainnya. Namun, yang jelas, pergaulan sehari-hari dengan berbagai problemnya itulah yang membuat pengarang harus menulis (wawancara, 5 April 2007).

Kelompok terdidik modern, sejak SD hingga perguruan tinggi, tentu saja juga memberi pengaruh yang penting, sehingga membuat Sunarta dapat melihat dan memahami Bali lebih intens dan kritis tentang Bali. Kelompok pendidikan modern diperolehnya melalui sekolah-sekolah yang ditempuhnya hingga perguruan tinggi. Ia menyelesaikan studi antropologi di Fakultas Sastra Universitas Udayana (tahun 2000), dan juga sempat mencicipi kuliah seni rupa di ISI Denpasar (2002-2003). Pola-pola kelompok pendidikan modern ini pulalah yang banyak diserap dan membentuk kediriannya selaku pengarang, sehingga ia dapat menilai bagaimana sistem yang melingkungi kehidupannya (wawancara, 11 Januari 2007).

Sunarta mengalami sosialisasi primer dan sekunder semuanya di kota Denpasar, Bali. Ia tidak pernah berpindah tinggal ke daerah lain. Karena itu, otomatis ia lebih banyak memahami dunia sosial itu melalui kelompok kota, pendidikan modern, dan profesional. Latar kelompok sosial dominan kota tentu saja sangat mempengaruhi kediriannya selaku pengarang. Hal ini sangat menentukan cara pandangnya selaku pengarang Bali.

\subsection{Pengarang dan Sistem Stratifikasi Sosialnya

$$
\text { Pengarang Bali hidup dalam }
$$
masyarakat Bali yang memiliki sistem pelapisan sosial yang hierarkis, yang membedakan manusia berdasarkan kasta atau gen-ekologisnya. Ada yang disebut lapisan kelas atas (brahmana, ksatria, wesia) atau triwangsa; dan lapisan kelas bawah (sudra) atau jabawangsa. Kelas atas disebut wong jero (orang dalam); sedangkan kelas bawah disebut wong jaba (orang luar). Adanya kelas atas dan kelas bawah menunjukkan masyarakat Bali 
terstratifikasikan secara vertikal (hierarkis). Jika dilihat dari sistem kastanya, ada empat tipe manusia Bali yakni tipe brahmana, ksatria, wesia, dan sudra.

Pengarang Rusmini dan Wijaya, kendatipun berasal dari kelas atas (brahmana, ksatria), namun mereka lebih senang menanggalkan nama gelar kasta dan ia lebih senang menggunakan nama pena "Oka Rusmini" dan "Putu Wijaya" saja, dan orangorang pun lebih mengenalnya tanpa embelembel gelar kasta. Ini terjadi karena mereka memiliki pemahaman tersendiri tentang kasta, sebagaimana yang diungkapkan pengarang Rusmini (wawancara, 10 Februari 2007).

Wijaya juga memiliki kesadaran akan kastanya, namun ia tidak meyakini sistem kasta karena cenderung membedakan manusia yang satu dengan manusia yang lainnya dalam derajat yang berbeda. Wijaya merasa tidak berbeda dengan teman-teman lainnya, walaupun dinyatakan dalam kelompok sosial yang berbeda (wawancara, 31 Januari 2007).

Sementara, Putu Fajar Arcana dan Wayan Sunarta tetap menggunakan nama pena yang lengkap dengan gelar nama kasta tanpa ada yang dihilangkan. Kendatipun Arcana dan Sunarta masih menggunakan nama gelar kasta pada nama dirinya, namun bukan berarti ia memiliki pandangan yang sama dengan orang Bali yang konservatif, yang meyakini sistem kasta. Pengarang Arcana juga menolak sistem kasta (wawancara, 13 Januari 2007). Arcana juga tidak meyakini sistem kasta, bukan karena keberadaan dirinya sebagai sudra, tetapi karena sistem itu dilihatnya mengandung ketidakadilan. Karena itu, sejak kecil sebenarnya ia ingin menggugat sistem itu, dan baru ia lakukan dan wujudkan setelah besar dan ketika menjadi penulis.

Pengarang Sunarta juga memiliki pemahaman serupa tentang kasta dengan tiga pengarang Bali yang telah diungkapkan. Bagi Sunarta, sistem kasta mengandung ketidakadilan. Ini sudah dirasakannya sejak pertama kali ia diajarkan tentang sistem kasta di SD, sehingga sejak dulu pula membuat dirinya ingin memprotesnya. Pandangannya ini terus hidup sampai besar dan dewasa, dan terutama ketika ia menempuh pendidikan tinggi (wawancara, 11 Januari 2007).

\subsection{Pengarang dan Relasi-relasi Sosialnya}

Ada berbagai relasi sosial yang dialami pengarang Bali dalam kehidupannya yang berpengaruh terhadap penciptaan cerpennya. Relasi sosial masing-masing pengarang Bali memang bervariasi meskipun sama-sama orang Bali. Ini karena mereka hidup dalam konteks situasi dan kondisi lingkungan sosial yang berbeda.

Pengarang Bali adalah orang Bali. Sejak kecil pengarang Bali sudah mengalami relasi sosial. Mula-mula dengan orang tuanya, dengan saudara-saudaranya, dan juga keluarga dekatnya. Dari relasi yang dialami pengarang Bali, ada relasi yang berupa: relasi otoriter, relasi demokratis, dan juga relasi patron-klien.

Dari dokumen biografis masingmasing pengarang Bali, dapat diungkapkan bahwa masing-masing pengarang itu menempuh pendidikan di sekolah yang berbeda. Ketika mengalami interaksi sosial di sekolah, pengarang mengalami relasi patronklien (guru-murid), otoriter (guru-murid), dan relasi demokratis (antarteman). Relasi ini dilanjutkan dalam relasi ketika remaja (berorganisasi) di dalam sekolah atau masyarakat dan dengan orang-orang berpengaruh. Kemudian, ketika dewasa dan sampai menempuh dunia pendidikan tinggi, mereka semakin dihadapkan pada dunia sosial atau kenyataan sosial yang makin spesifik dan baru. Dalam interaksi pengarang Bali, banyak nilai sebagai dunia objektif masyarakat Bali yang tidak sesuai dengannya. Misalnya, norma yang berkait dengan sistem kasta yang membedakan derajat manusia (wawancara, 10 Januari 2007). Berbagai realitas kehidupan sehari-hari yang tidak manusiawi dialami menginspirasi dirinya untuk menciptakan karya-karyanya yang bernuansa menggugat (wawancara pengarang, 7 April 2007). Rusmini juga memahami bahwa kehidupan dalam masyarakat Bali yang sudah campur-aduk terjadi sebagai akibat dari modernisasi di Bali. 
Begitu juga halnya dengan yang dialami pengarang Arcana, Wijaya, dan Sunarta. Arcana bersikap kritis atas realitas sosial yang ada di Bali dan menolak beberapa dunia objektif yang diinternalisasinya berkait dengan adat kematian, perkawinan, dan pewarisan, ia menolak sisi-sisi ketidakadilannya (wawancara, 13 Januari 2007). Wijaya adalah orang yang kritis terhadap setiap fenomena apa pun, dan tidak terkecuali tentang Bali, di mana ia mengalami internalisasi tingkat pertama (primer); misalnya, tentang penolakannya pada konsep identitas ke-Bali-an (wawancara, 31 Januari 2007).

\subsection{Pengarang dan Institusi-institusi Sosialnya}

Pengarang Bali memang tidak lepas dengan institusi-institusi sosial yang melingkunginya. Pngarang Bali adalah anggota beberapa kelompok sosial, mereka sekaligus juga adalah anggota yang terlibat dalam pembiasaan pola-pola yang ada pada institusiintitusi sosial di lingkungan hidupnya.

Pengarang Rusmini terlibat dalam aktivitas di banjar dan institusi modern. Polapola yang ada dalam institusi sosial itu membentuk kediriannya, juga dunia akademis (perguruan tinggi) dan dunia kerja (Bali Post), membuat Rusmini juga lebih mampu melihat dan memahami masyarakat Bali secara lebih faktual dan aktual (wawancara, 10 Januari 2007). Kelahiran karya cerpennya banyak terinspirasi dari keterlibatan dirinya dalam dunia sosial secara empirik. Rusmini (wawancara, 7 April 2007) juga menjawab bahwa hierarkis kasta sebagai yang paling mempengaruhi dirinya dalam menciptakan cerpennya.

Pengarang Arcana, juga hidup dan melakukan pembiasaan dengan pola-pola institusi banjar, sehingga pola-polanya juga mempengaruhi dirinya. Ia juga dipengaruhi dunia pendidikan tinggi dan dunia kerja (sebagai wartawan Nusa, Tempo, dan kemudian Kompas) (wawancara, 13 Januari 2007). Setelah tinggal di luar Bali, ia tidak lagi terpengaruh oleh institusi banjar atau desa adat, namun ia masih memiliki keterikatan emosional dengan Bali (wawancara, 8 April 2007).

Pengarang Wijaya, juga melibatkan diri dalam institusi sosial banjar di Bali, meski singkat. Wijaya memahami, institusi tradisional Bali bermakna penting, terutama karena filosofisnya yang bermanfaat untuk hidup manusia. Institusi pendidikan modernlah yang lebih banyak mempengaruhi Wijaya. Ia tidak hanya melibatkan diri dalam institusi pendidikan modern, tetapi juga dalam aktivitas modern di luar dunia pendidikan modern dan juga dunia kerja (institusi kantor keredaksian Tempo). Pola-pola yang ada pada institusi pendidikan modern dan kantor keredaksian inilah yang paling berpengaruh pada diri Wijaya selaku pengarang Bali.

Pengarang Sunarta, tampak memang terlibat juga dengan institusi banjar, kendatipun ia hidup di pusat kota Denpasar. Institusi pendidikan modern dan Sanggar Teaterlah yang tampak paling dominan mempengaruhi dirinya selaku pengarang. Polapola yang ada dalam institusi pendidikan membuatnya dapat lebih peka dalam memahami persoalan-persoalan dalam masyarakat Bali.

\subsection{Pengarang dan Kisaran Nilai-nilai}

$\mathrm{D}$ a $1 \mathrm{a} \mathrm{m} \mathrm{menge} \mathrm{m} \mathrm{b} \mathrm{a} \mathrm{gk}$ a n kehidupannya, pengarang Bali tidak lepas dengan nilai-nilai yang mengitarinya. Nilai yang ada yakni nilai komunitas ke-brahmanaan, ke-sudra-an, ke-satria-an, nilai ritual, nilai patriotis, dan nilai manusiawi.

Pengarang Rusmini, ketika ia masih menjadi anggota kelompok griya, banjar, dan desa, menginternalisasi nilai-nilai kebrahmana-an ke dalam dirinya, namun juga diawali dengan nilai metropolis ketika tinggal di Jakarta. Ia tidak hanya dipengaruhi oleh nilai ke-brahmana-an, tetapi juga nilai ritual, patriotis, dan manusiawi. Nilai ke-brahmanaan dan nilai ritual itu diserapnya ketika ia hidup di desa atau griya (wawancara, 10 Januari 2007). Nilai manusiawi diperolehnya terutama melalui dunia pendidikan dan media, serta profesi dirinya sebagai wartawan Bali Post, 
yang memiliki akses yang luas dan terbuka (wawancara, 7 April 2007).

Pengarang Arcana, menginternalisasi nilai-nilai tradisi yang berupa ke-sudra-an, dan juga banjar dan desa. Ia juga menyerap nilainilai yang bersifat komunal dalam kelompok banjar dan desa. Arcana kemudian lebih banyak menginternalisasi nilai-nilai patriotis dan manusiawi. Kedua nilai tersebut juga diperolehnya melalui dunia pendidikan dan dunia media. Oleh karena Arcana juga sekaligus wartawan, tentu memberi peluang yang luas untuk menginternalisasi nilai-nilai yang lebih jauh.

Pengarang Wijaya, lebih banyak melibatkan diri dalam pergaulan nasional dan internasional, yang melampaui pergaulan komunitas kstaria, banjar, atau desanya. Karena itu, nilai-nilai komunitas patriotis dan manusiawilah yang paling banyak diinternalisasi dan mempengaruhi dirinya sebagai pengarang. Wijaya memang sempat menginternalisasi nilai-nilai tradisi yang bersumber dari nilai ke-ksatria-an, banjar, dan desa, tetapi hanya sebentar saja.

Pengarang Sunarta, menginternalisasi nilai-nilai ke-sudra-an dan nilai-nilai tradisi Bali. Nilai-nilai patriotis dan manusiawi, lebih banyak diinternalisasi melalui dunia pendidikan dan dunia media. Ia memang bukan wartawan tetapi pekerja budaya dan teater (wawancara, 11 Januari 2007), dan banyak dipengaruhi nilai-nilai tradisi yang terdapat dalam dongeng dan wayang. Cerita-cerita dongeng itulah yang membangkitkan imajinasinya (wawancara, 5 April 2007). Ia juga menginternalisasi nilai-nilai melalui teknologi komunikasi modern, karena ia suka membaca buku-buku dan terbitan-terbitan lainnya, juga karena akrab dengan dunia internet.

\section{Pemanfaatan Adat oleh Pengarang}

Dunia sosial Bali tidak terlepaskan dengan adat Bali. Orang Bali yang tinggal di Bali biasanya menggunakan adat Bali sebagai panduan hidupnya, termasuk juga halnya pengarang Bali. Dunia kehidupan mereka selalu berkait dengan adat Bali. Sebab, hidup di Bali adalah hidup dalam dunia adat. Namun, ada perbedaan di antara pengarang Bali, jika ditilik dari keterlibatan mereka dengan adat Bali. Ada variasi pada mereka, karena intensitas yang berbeda.

Pengarang Rusmini, Arcana, Putu Wijaya, dan Sunarta semuanya mengkritisi adat yang dianggapnya banyak yang harus disesuaikan dengan kondisi masyarakat Bali yang berubah seiring dengan proses modernisasi. Meskipun pengarang Bali tampak mengritik adat, namun sebenarnya ia mengritik modernitas.

Pengarang Bali menulis adat memang berangkat dari ketidakpuasannya dengan adat Bali, karena mereka semua mengalami bagaimana pembedaan atau diskriminasi dilakukan. Lahirnya karya-karya yang memanfaatkan adat ini, sebagai respons pengarang untuk mengritik adat yang dinilainya masih belum memberi keadilan bagi semua orang dalam adat Bali.

\section{Pemanfaatan Modernitas oleh Pengarang \\ Pengarang Bali adalah orang Bali yang} akrab dengan adat. Pengarang Bali juga sudah banyak bersentuhan dengan kehidupan dunia modern. Kondisi masyarakat Bali yang semakin modern disertai dengan pesatnya industri pariwisata juga semakin mempercepat proses modernisasi di Bali.

Pengarang Bali adalah orang-orang yang telah bersentuhan dengan modernitas dan memiliki pola pikir yang cenderung memanfaatkan modernitas, sehingga mereka cenderung menjadi lebih kritis dan objektif dalam memandang realitas sosial Bali. Pengaruh modernitas hadir sebagai kekuatan pengarang Bali dalam melontarkan gugatannya atas dunia sosial Bali yang dianggap perlu diperbaiki untuk kebaikan Bali.

\section{Gerak-balik dan Kerancuan Adat- modernitas Pengarang \\ Pengarang Bali tidak hanya sadar} sebagai orang Bali, tetapi sadar juga harus dapat 
berperan sebagai orang modern yang berguna untuk kebaikan Bali. Pengarang Bali mengritik orang Bali, sistem, adat, dan kondisi Bali secara keseluruhan, bukan berarti memusuhi Bali tetapi justru karena memiliki perhatian yang sangat besar pada dunia sosial Bali.

Pengarang Bali memiliki kesadaran penuh menulis tentang Bali. Ini karena mereka memang merasa sebagai orang Bali, yang mengalami dan melihat berbagai persoalan tentang Bali. Sebagai orang Bali, ia merasa wajib menuliskan berbagai persoalan atau kasus yang dipandang pengarang mendegradasi Bali, atau paling tidak menyelaminya. Mereka mencoba menawarkan ide-ide kecil untuk kemungkinan pemecahannya, agar Bali menjadi modern.

Pengarang Bali memang sadar sebagai orang Bali yang harus menjadi orang modern. Namun, di luar kesadarannya itu, pengarang Bali sangat terikat dan mencintai dunianya. Bali yang mereka bayangkan adalah Bali dengan tradisinya, sehingga pengarang Bali acapkali kembali kepada tradisi ketika membayangkan Bali. Terjadi gerak-balik adat-modernitas yang dialami pengarang. Dari keberadaan dirinya yang akrab dengan dunia adat ia ingin menjadi modern. Namun, dalam dunianya yang modern ia acapkali kembali kepada pemacahan yang bertopang pada adat.

Berbagai kerancuan adat-modernitas yang ada dalam dunia sosial karya, berkait dengan kerancuan adat-modernitas yang dialami pengarang Bali. Dari hasil wawancara dengan pengarang Bali, dapat dikemukakan bahwa ada berbagai keinginan yang juga mencerminkan kerancuan yang ada pada dirinya.

Memang terdapat kerancuan adatmodernitas dalam dunia sosial pengarang Bali. Pengarang yang mengritik adat sebenarnya mengritik modernitas. Itu dapat disimak dari berbagai pernyataan yang disampaikan oleh pengarang Bali. Bagi pengarang Bali juga, Bali memang harus berubah tetapi menuju perubahannya yang maju dan bukan yang justru mengakibatkan kehancuran bagi Bali. Pola pikir orang-orang Bali dianggap sebagai penyebab kehancuran Bali.

\section{Masyarakat yang Diidealkan Pengarang Bali}

Dalam dunia sosial karya, pengarang mencoba melukiskan dunia sosial masyarakat Bali. Pengarang mengkonstruksi masyarakat yang dikehendakinya, yang terbangun dari pengalaman pengarangnya yang hidup dalam masyarakat Bali yang sudah mendapat pengaruh modernisasi atau yang sudah campuraduk.

Adapun masyarakat yang diidealkan pengarang Bali adalah: (1) masyarakat yang tidak terkelompokkan secara hierarkis sebagai akibat penerapan sistem kasta, tetapi sesuai dengan prinsip sistem warna, yang mengelompokkan masyarakat berdasarkan profesi atau keahliannya, (2) masyarakat yang menghargai kesetaraan dan kesederajatan sebagai manusia, (3) masyarakat lebih mengedepankan cara pikir rasional dan modern, (4) masyarakat Bali yang memberi identitas Bali tidak berdasar atribut luarnya saja tetapi dari batin, serta (5) masyarakat yang mengakui kebebasan asasi manusia, untuk memilih dan dipilih.

\section{PENUTUP}

Ada tiga simpulan yang dapat diungkapkan dalam studi ini. Pertama, pengarang Bali mengusulkan secara subjektif penataan-ulang pola pikir modern orang-orang Bali dalam menghadapi modernisasi atau kondisi Bali pada saat ini yang berubah. Kedua, para pengarang Bali dapat dikatakan berada di perbatasan sebagai manusia yang mendua, yakni di satu sisi menggugat atau mengritisi Bali; di sisi lain membela atau mencintai Bali. Kemenduaan itu terjadi karena Bali memang pada saat ini tengah menghadapi masa krisis dan rumit (complicated). Ketiga, pengarang Bali menawarkan suatu kebenaran yang tidak bersifat dogmatis tetapi yang bersumber dari pengalaman sehari-hari. Bagi pengarang, yang terpenting adalah memanusiakan individu- 
individu manusia di tengah masyarakat Bali, dan bukan mematuhi begitu saja sistem sosial dalam masyarakat Bali.

\section{DAFTAR PUSTAKA}

Arcana, Putu Fajar. 2003. Bunga Jepun. Jakarta: Kompas.

Berger, Peter L. \& Thomas Luckmann. 1990. Tafsir Sosial atas Kenyataan: Risalah tentang Sosiologi Pengetahuan (diterjemahkan dari buku asli The Social Construction of Reality oleh Hasan Basari). Jakarta: LP3ES.

Berger, Peter L. 1991. Kabar Angin dari Langit: Makna Teologi dalam Masyarakat Modern (diterjemahkan dari buku asli A Rumor of Angels: Modern Society and the Rediscovery of the Supernatural oleh J. B. Sudarmanto). Jakarta: LP3ES.
Damono, Sapardi Djoko. 1984. Sosiologi Sastra: Sebuah Pengantar. Jakarta: Pusat Pembinaan dan Pengembangan Bahasa.

Koastanto. 2007. "Memperbaiki Tusan yang Porak Poranda". Kompas, April, halaman 17.

Putra, I Nyoman Darma. 2003. "Narasi Polos 'Kekerasan' Adat Bali”, dalam Kompas, 20 Desember 2003, halaman 47.

Rusmini, Oka. 2002. Sagra. Magelang: IndonesiaTera.

Sunarta, Wayan. 2005. Cakra Punarbhawa. Jakarta: Gramedia Pustaka Utama.

Teeuw, A. 1984. Sastra dan Ilmu Sastra. Jakarta: Pustaka Jaya.

Wijaya, P. 2004. Bali. Jakarta: Kompas. 